HUGH WOOD. Piano Trio (première)-IOMay/ Brighton Festival / Parikian-Fleming-Roberts Trio.

DOUGLAS YOUNG. Song of Exile (première)-8 May / Wigmore Hall / Ashley Stafford (counter-tenor), Penelope Smith (piano). Lament on the Destruction of Forests (première)I5 May / Leicester Cathedral / Debu Chaudhuri (sitar), Leicestershire Schools Symphony Orchestra c. Peter Fletcher.

\section{Periodicals}

\section{MUSIC ANALYSIS}

Vol. 2 Number 2 July 1983

Robert Hanson, Webern's Chromatic Organization, pp. 135-149. Anthony Pople, Skryabin's Prelude, op. 67, No. I: Sets and Structure, PP. 15I-173.

\section{STUDIA MUSICOLOGICA ACADEMIAE}

\section{SCIENTIARUM HUNGARICAE}

Tomus XXV, Fasciculi I-4, 1983

A Kodály Number, including Bálint Sárosi, Instrumental Folk Music in Kódaly's Works, pp. 25-38. Ferenc Bónis, Zoltán Kodály, a Hungarian Master of Neoclassicism, pp: 79-98. Deszö Legány,
Kodály and the Three Choirs Festival, pp. 99-108. János Breuer, Anton Webem dirigiert Kodály, pp. I 19. Also James Porter, Bartók and Grainger: Some Correspondences and a Hypothesis, pp. 239-248. András Wilheim, Erik Satie's Gregorian Paraphrases, pp. 249-258.

Books Received

( $A$ listing in this column does not preclude a review in a future issue of TEMPO)

ARNOLD SCHOENBERG / WASSILY KANDINSKY: Letters, Pictures and Documents edited by Jelena Hahl-Koch, translated by John C. Crawford. Faber \& Faber, £20.00 hardback, £9.95 paperback.

FINANCIAL SCRUTINY OF THE ROYAL OPERA HOUSE, COVENT GARDEN LTD. by Clive Priestley, CB. (Report to the Earl of Gowrie, Minister for the Arts). HM Stationery. Office, $\{18.00$.

ALTERNATIVE VOICES: Essays on Contemporary Vocal and Choral Composition by Istvan Anhalt. University of Toronto Press, \&29.75.

\title{
GYÖRGY KURTÁG
}

\author{
at the Bath Festival
}

Eight Deszö Tandori Choruses (WORLD PREMIERE)

1 June: BBC Singers conducted by John Poole

12 Microludes for String Quartet

31 May: Eder String Quartet

String Quartet No. 1

3 June: Arditti String Quartet

Játékok

7 June: György and Marta Kurtág

Messages of the Late Miss R. V. Troussova

8 June: Adrienne Csengery (soprano), London Sinfonietta

c. Diego Masson

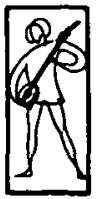

EDITIO MUSICA BUDAPEST SOLE U.K. agents BOOSEY \& HAWKES Music Publishers Limited 